УДК 796.035 : 796.012.65-053.81

Свгеній Імас, Мирослав Дутчак, doi: 10.15330/fcult.33.3-10

\title{
ПІДВИЩЕННЯ РІВНЯ ЗАЛУЧЕНОСТІ ОСІБ ЗРІЛОГО ВІКУ ДО УЧАСТІ У ОЗДОРОВЧО-РЕКРЕАЦІЙНИХ ЗАХОДАХ
}

\begin{abstract}
Метою дослідження було вивчення та систематизачія підходів до підвищення рівня залучення осіб зрілого віку до занять оздоровчо-рекреачійною діяльністю. Методи дослідження - теоретичний аналіз спечіальної науково-методичної літератури, документальних матеріалів, педагогічні, сочіологічні методи дослідження, методи оцінки рухової активності, методи математичної статистики. Результати: на основі аналізу, узагальнення, порівняння науково-методичної літератури та отриманих емпіричних даних нами було досліджено иільову аудиторію учасників забігів та виявлено особливості залучення різних груп населення до масових оздоровчо-рекреаційних заходів в Україні. Нами було досліджено сочіальні передумови рекреаџійної діяльності вітчизняних та зарубіжних оздоровчорекреаційних заходів за даними спеціальної літератури. Виявлено, щзо більшість учасників забігів в Україні - це люди з міст мільйонників (Київ, Одеса, Львів), виявлено проблему відсутності бігової культури в багатьох містах та селах України. В рамках ситуації, щуо склалася в Україні, нами було запропоновано підходи до залучення більшої кількості людей до занять оздоровчо-рекреаційними заходами: проведення рекламної кампанії, побудованої на меседжі бігунів, створення онлайн $і$ офлайн програми підготовки для різної аудиторії, від новачків до досвідчених бігунів; проведення лекцій на бігову тематику; створення єдиної бази бігових клубів України з метою покращити підготовку бігунів та розширити аудиторію любителів бігу загалом; створення дистаниї в рамках забігу з благодійною метою. На основі отриманих даних розроблено рекомендації із залучення осіб зрілого віку до занять оздоровчо-рекреаційною активністю, на прикладі масових забігів.
\end{abstract}

Ключові слова: рухова активність, забіги, оздоровчо-рекреаційні заходи, особи зрілого віку

The aim of the research is to study and systematize approaches that increase the level of adults' involvement to recreation and wellness activities. Methods of research include the following: theoretical analysis of special scientific and methodical literature, documentary materials; pedagogical and sociological methods of research, methods of motor activity assessment, and methods of mathematical statistics. Results of the research are the following: on the basis of analysis, generalization and comparison of scientific and methodological literature as well as obtained empirical data, we have studied the target audience of the participants of racing competitions and identified the specifics of involving different population groups in mass recreation and wellness activities in Ukraine. We have analysed social preconditions for recreational activities at domestic and foreign recreation and wellness events according to the data of special literature. It has been revealed that the majority of races participants in Ukraine are people from highly-populated cities (Kyiv, Odesa, Lviv); moreover, we have discovered the problem of absence of running culture in many cities and villages of Ukraine. In the current situation that exists in Ukraine, we have proposed some approaches to attracting more people to health and recreation activities: running an advertising campaign built on runners' messages, creating an online and offline training program for different target audiences: from beginners to experienced runners; organising lectures on running topics; creating a single base of the Ukrainian racing clubs in order to improve runners ' training and expand the audience of people keen on racing in general; creating the race on certain distance aimed at charitable purposes. On the basis of the obtained data, we have developed recommendations for attracting adults to recreation and wellness activities, providing the example of organising mass running races.

Key words: motor activity, races, recreation and wellness activities, adults.

Постановка проблеми й аналіз результатів останніх досліджень. Збереження здоров'я та повноцінного життя громадян, формування здорового способу життя є однією з найважливіших цілей сталого розвитку світової спільноти [12]. Проблема здоров'я осіб різного віку названа одним з пріоритетних напрямів діяльності ВООЗ у XXI сторіччі $\epsilon$ вкрай актуальною і для України [11]. Недосконалість системи охорони здоров'я, низький рівень усвідомлення цінності здоров'я як власного капіталу, перебування переважної більшості населення в умовах соціально-економічної нестабільності призвели до створення несприятливих для ведення здорового способу життя умов $[6,10]$. Дослідження багатьох авторів дають підстави стверджувати, що значна частина населення має недостатній обсяг рухової активності $[2,4,7,9,13]$. Задля покращення ситуації в 
Україні та підвищення рівня рухової активності населення, протягом багатьох років проводяться активна робота 3 пошуку ефективних засобів їхнього залучення до фізкультурно-оздоровчих занять $[5,6,11]$. Зокрема, високою популярністю користуються масові рекреаційні заходи які спонукають громадян до систематичних фізкультурнооздоровчих занять $[1,5]$. Аналіз літературних джерел та інформаційних ресурсів мережі Інтернет, здійснений Л.В. Пасічняком, із впровадження спортивної анімації у місцях масового відпочинку населення свідчить, що вказана проблема обумовлена протиріччями між значними потенційними можливостями оздоровчо-рекреаційної рухової активності розважального характеру для підвищення ефективності відпочинку й ведення здорового способу життя різних груп населення та недостатньою реалізацією цих можливостей у місцях масового відпочинку населення [9].

В останні роки проводяться дослідження, присвячені проведенню масових рекреаційних заходів, ведуться пошуки щодо впровадження в практику інновацій при організації та проведенні, зокрема: “Ярмарок спорту”, “Тиждень доступного спорту”, “Мама, тато, я спортивна сім'я”, “Козацькі забави", "Nova Poshta Kyiv Half Marathon”, "Wizz Air Kyiv City Marathon" тощо. Здійснюється це з метою збільшення кількості залучених до систематичних рекреаційних занять.

Важливим чинником у підвищенні ефективності проведення масових заходів рекреаційного характеру є приведення їх у відповідність до вимог сучасного потенційного споживача фізкультурно-оздоровчих послуг. Тому ми вважаємо, що важливим та актуальним $\epsilon$ підвищення участі у оздоровчо-рекреаційних масових заходах. Оздоровчорекреаційна рухова діяльність відзначається динамізмом, різноманіттям форм, напрямів, універсальністю їх використання, орієнтованих на максимальне задоволення амбіцій людей, створення культурного простору в соціумі $[2,3]$. На думку науковців, фізична рекреація постає як глобальне явище, що має стабільні темпи зростання. Іїі вважають одним із перспективних напрямків соціально-економічного розвитку, оскільки вона проявляється на конкретній території, шляхом дії об'єктивних умов і суб'єктивних чинників, які забезпечують переваги іiї розвитку на цих територіях. Вищенаведене підкреслює перспективність, необхідність і актуальність наукових досліджень з розробки підходів до залучення людей різних вікових категорій до участі у масових оздоровчорекреаційних заходах.

Дослідження виконано відповідно до Плану наукової роботи НУФВСУ на 20162020 рр. згідно з темою кафедри здоров'я, фітнесу та рекреації “Теоретико-методологічні засади оздоровчо-рекреаційної рухової активності різних груп населення” (номер держреєстрації 0116U001630).

Мета дослідження - вивчити та систематизувати підходи до підвищення рівня залучення осіб зрілого віку до занять оздоровчо-рекреаційною діяльністю.

Методи дослідження: теоретичний аналіз спеціальної науково-методичної літератури, документальних матеріалів, педагогічні, соціологічні методи дослідження, методи оцінки рухової активності, методи математичної статистики.

Результати дослідження та їх обговорення. Для того щоб залучати до оздоровчо-рекреаційних заходів більшу кількість людей, потрібно дослідити та створити портрет цільової аудиторії. За основу ми вирішили взяти протоколи забігів Run Ukraine Running League 2017, що налічують 5 забігів у чотирьох містах України: Київ, Одеса, Львів, Дніпро [8]. Ми визначили портрет цільової аудиторії. Під портретом аудиторії розуміли визначення поведінки, потреб та інших характеристик, які характерні для більшості аудиторії. Наявність такої інформації спрощує створення маркетингової стратегії для просування забігів, як одного з видів оздоровчо-рекреаційних заходів, залучення та збільшення кількості учасників. 
В кожному забігу Run Ukraine Running League є дистанції для дітей та дорослих, для людей, що тільки починають бігати та для досвідчених бігунів. Аналіз портрету учасника здійснювався в розрізі окремих дистанцій та всіх учасників загалом. В першому забігу 2017 року - Nova Poshta Kyiv Half Marathon, прийняло участь 8924 учасника, з них 2887 осіб здолали дистанцію 21,0975 км (рис. 1). Така кількість учасників перевищує кількість 2016 року на 1824 особи. Серед учасників забігів є також представники з різних країн, які приїздять в Україну не тільки з метою пробігти півмарафон, а й відвідати туристичні місця. В 2017 році на Nova Poshta Kyiv Half Marathon приїхало 420 іноземців, найбільша кількість з Білорусії - 85 учасників, США - 30 учасників, Німеччини - 17 учасників. Що ж стосується України, то тут серед міст лідирує Київ 7146 учасників серед 8924 осіб. Друге місце посідає Одеса - 109 учасників, та Львів 108 учасників. Однак, якщо порівнювати 3 минулими роками, тенденція учасників 3 інших міст України значно зростає. Наприклад, в 2016 році на Nova Poshta Kyiv Half Marathon $з$ Одеси було 48 учасників, зі Львова - 45. Популяризацію бігу в містах України відбувається завдяки відкриттю місцевих бігових клубів та проведенню забігів в регіонах України.

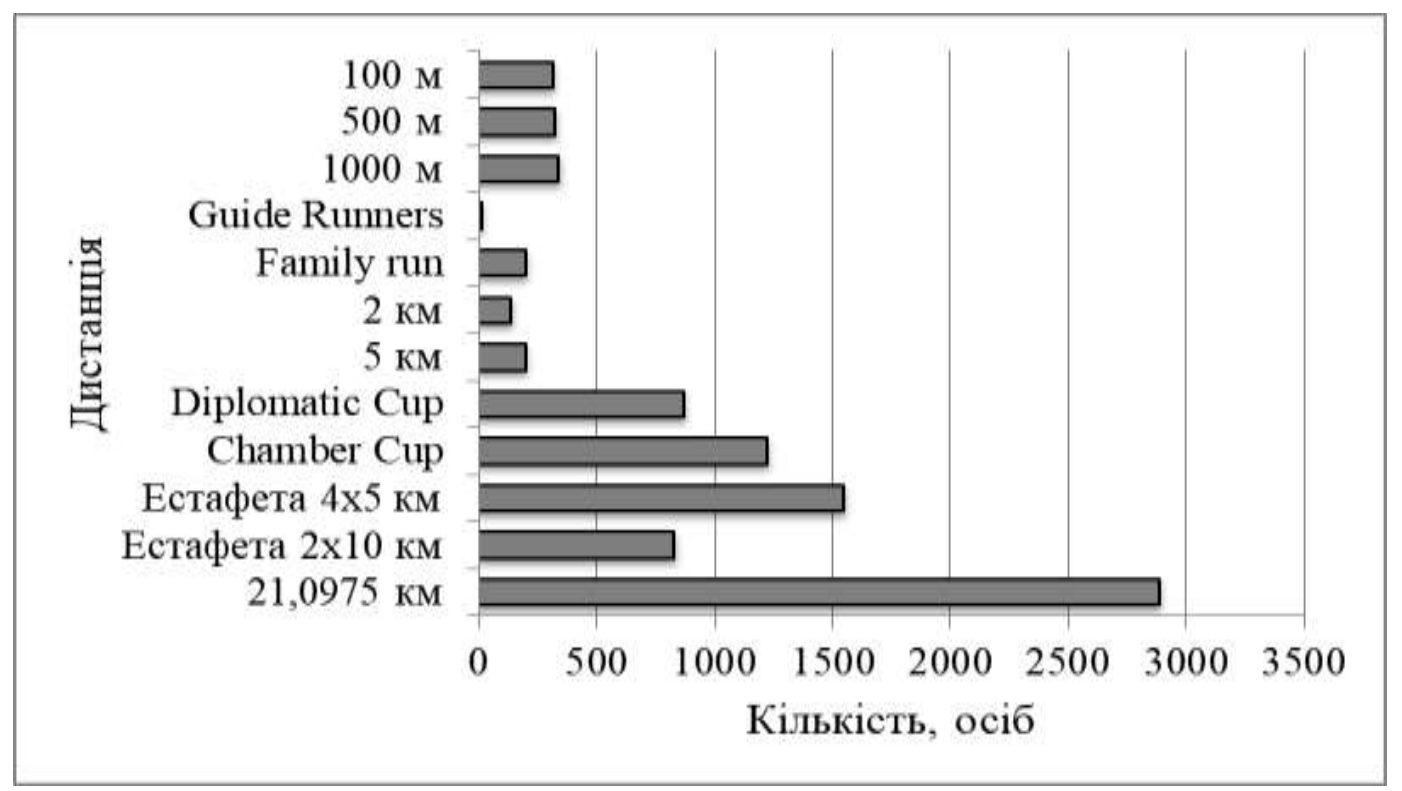

Puc. 1. Кількість учасників Nova Poshta Kyiv Half Marathon по дистанціях

Аналіз гендерного співвідношення слід проводити у розрізі найдовшої дистанції забігу - 21,0975 км, та у розрізі інших дистанцій: 10, 5 та 2 км. Як ми можемо побачити на рис. 2 на півмарафонській дистанції лідирують чоловіки, лише $21 \%$ - тобто 577 жінок здолали дистанцію 21,0975 км в рамках Київського півмарафону. Що ж стосуються менших дистанцій - 10, 5 та 2 км - то тут кількість жінок і чоловіків приблизно однакова: 57\% чоловіків проти 43\% жінок. Якщо порівнювати аудиторію з 2016 роком, то кількість фінішерів на півмарафонській дистанції серед жінок зросла, майже вдвічі (на 250 учасників).

Віковий профіль учасників забігів в рамках Nova Poshta Kyiv Half Marathon варіюється від 1 року (дитячі дистанції) до 78 років, однак найбільша кількість учасників - це аудиторія осіб першого періоду зрілого віку 25-35 років (рис. 2). Згідно регламенту змагань, на дистанцію півмарафон допускаються учасники 318 років. Для дистанцій 
10 та 5 км вікове обмеження триває до 16 років, а дистанцію 2 км можна долати після 14 років.

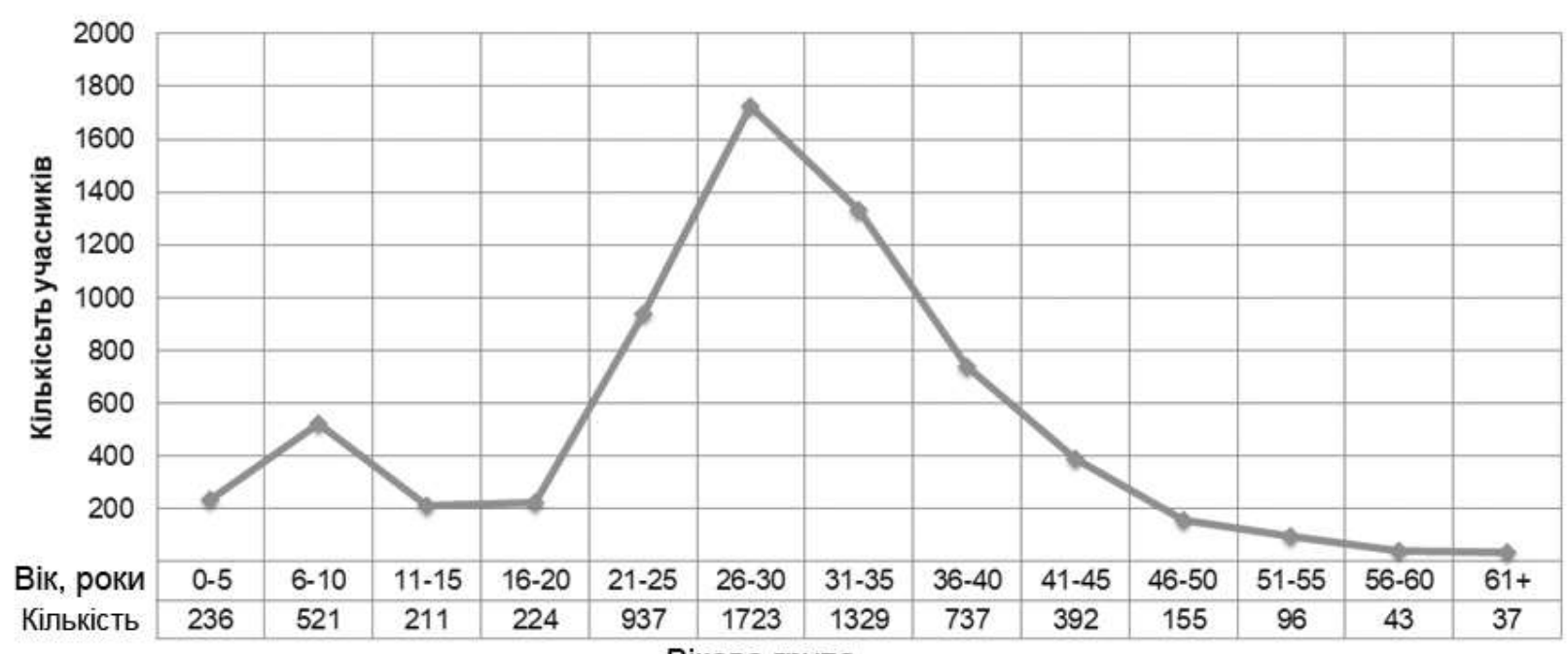

Вікова група

Puc. 2. Віковий профіль учасників забігу Nova Poshta Kyiv Half Marathon 2018

(у розрізі всіх дистанцій)

Окрім цього, в рамках забігу відбуваються дитячі забіги на 100, 500 та 1000 метрів, тут вікові обмеження варіюються від 1 до 13 років, залежно від дистанції. Соціальний профіль учасників подано на рис. 3. Значна кількість учасників є приватними підприємцями, а також працюють в IT-сфері та галузі фізичної культури і спорту.

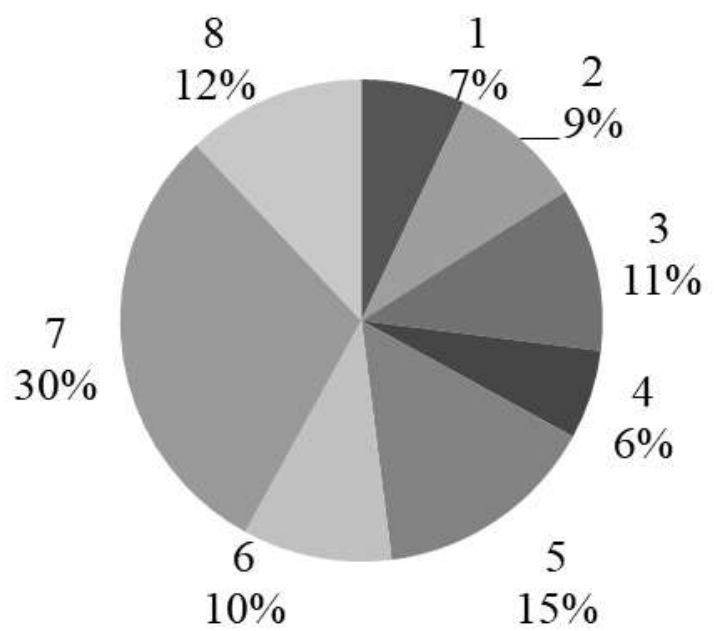

Puc. 3. Соціальний профіль учасників забігу: 1 - студенти; 2 - реклама/маркетинг; 3 - IT сфера; 4 - юриспруденція; 5 - приватні підприємці; 6 - спорт; 7 - інше; 8 - економіка

За результатами опитування ми виявили мотиви до участі у масових забігах, як одного із видів оздоровчо-рекреаційної рухової активності, серед них: підтримання фізичної форми, оздоровлення, покращення власних результатів на дистанції, біг за медаль, біг за компанію з друзями, біг з метою довести самому собі, що в змозі здолати півмарафонську дистанцію.

3 метою популяризації здорового способу життя, занять фізичною культурою та спортом нами було розроблено та запропоновано шляхи залучення людей різних віко- 
вих категорій до участі у масових оздоровчо-рекреаційних заходах на прикладі забігів. Для того щоб долучати людей до бігу, потрібно спочатку навчити їх правильно бігати, щоб ця активність приносила їм здоров'я та задоволення. Для цього пропонується створити онлайн та офлайн програму підготовки осіб різних вікових категорій до подолання дистанцій від 2 до 42 кілометрів. Мета: створення інформаційного поля для залучення уваги аудиторії до бігових заходів; зменшення травматичних випадків під час забігів; підвищення рівня бігової культури в цілому. Завдання: сприяння правильній, грамотної підготовці учасників до обраної дистанції; привернення уваги громадськості до бігових заходів; створення інформаційних приводів; збільшення кількості відвідувань офіційних сайтів забігів. В рамках офлайн напряму підготовки пропонується проводити раз на тиждень відкриті тренування з бігу, розраховані на три групи: новачки, які готуються пробігти 2 км; група на 5 та 10 км; досвідчені бігуни, що готуються до півмарафону або марафону. Після кожного тренування на сайті буде публікувати завдання на тиждень, окремо для кожної групи підготовки. Окрім цього, офлайн формат надасть змогу учасникам познайомитися з тренерами та задати їм питання про екіпірування, правильне харчування під час підготовки до забігу та інше.

Нами було проведено анкетування учасників забігу з метою дізнатися, як саме вони готуються до забігу. Як виявилося, 77,6\% опитаних (серед 745 респондентів) готуються до забігів самостійно, 17,4\% у клубі любителів бігу, решта з персональним тренером. Тому пропонується створити онлайн платформу, де учасники зможуть отримувати інформацію про підготовку, читати статті на бігову тематику, дивитися відео про правильну техніку бігу, способи виконання спеціальних бігових вправ, та інше.

На сайті заходу рекомендовано створити розділ зі спеціалізованим відео і текстовим контентом на бігову тематику, з порадами від тренерів на різні теми, приклад: як правильно підібрати екіпірування для бігу; правильна техніка бігу; як правильно відновлюватися після тренування; як правильно харчуватися під час підготовки до забігу. Окрім цього, в рамках підготовки до забігу, пропонується проводити лекції з теорії $\mathrm{i}$ методики занять оздоровчим бігом.

На сьогоднішній день немає єдиної бази або сайту, де була б зібрана інформація про бігові ком'юніті України. У Києві бігових спільнот більше, в регіонах ситуація йде набагато гірше. На основі цієї проблеми, нами було сформовано цілі: створення i розвиток стабільного бігового ком'юніті на всій території України (не тільки в Києві); збільшення учасників на довгих дистанціях в стартах Run Ukraine; зменшення травматичних випадків на заходах. Завдання для досягнення поставлених цілей: виміряти ринок бігових клубів, зібрати інформацію по місткість ринку; встановити партнерські відносини $з$ клубами; перетворити клуби в “адвокатів” бренду Run Ukraine; стати майданчиком, на якому бігуни і клуби зможуть встановлювати “контакт” один з одним; розробити систему лояльності і вибудувати роботу з клубами. Run Ukraine розроблено пропозиції для розвитку бігових клубів в Україні та формування відносин 3 ними: створити платформу на сайті Run Ukraine з картою бігових клубів по всій Україні. Для зацікавленості клубів надано можливість розміщувати інформацію на сайті Run Ukraine з лінками і контактами. Раз на квартал робити розсилку з інформацією про бігові клубі по базі учасників. Кожен клуб, який стане членом Run Ukraine отримає знижку на бігові старти. Клуби отримують від Run Ukraine одну безкоштовну реєстрацію для розіграшу в соціальних мережах. За підсумками року ми зможемо створити три групи по залученості і вже в 2019 році давати клубу від 2 до 5 реєстрацій безкоштовно на сезон. В рамках Nova Poshta Kyiv Half Marathon 2018 створити вечірку для бігових клубів напередодні старту (п'ятниця) i в суботу екскурсійну пробіжку містом. Підготовка заочних програм підготовки для бігунів різних рівнів. Таким чином, чим більше 
бігових клубів буде створено по всій Україні, тим більшою бігова спільнота буде ставати, і тим більше учасників буде приймати участь у забігах.

Наймасовіший забіг в України - "Київський пробіг під каштанами", в проходив 26-й рік поспіль. Його популярність (більше 25000 учасників) обумовлена його метою: кошти, зібрані в рамках "Пробігу під каштанами” уже 17-й рік поспіль передаються Центру дитячої кардіології та кардіохірургії МОЗ України для закупівлі необхідного обладнання та витратних матеріалів. Тому, ще однією пропозицією для залучення більшої кількості людей до участі у забігах Run Ukraine - додати благодійну складову, мета якої - зібрати кошти та залучити громадськість до вирішення конкретної проблеми. Для цього найменшу дистанцію в рамках забігу - 2 км, пропонується зробити благодійною, 50\% реєстрації з якої буде йти на благочинність.

Висновки. Оздоровчо-рекреаційні заходи сприяють поліпшенню здоров'я населення, підвищенню фізичного та емоційного стану, покращають самопочуття. В Україні за останні 10 років активно розвиваються і набувають популярності бігові заходи серед любителів бігу, як один із видів оздоровчо-рекреаційної активності. В ході дослідження нами було проаналізовано старти Run Ukraine Running League за 2017-й рік та створено портрет цільової аудиторії. Як виявилося, серед учасників півмарафонів, беззаперечну більшість займають чоловіки від 25 до 36 років. I не дивлячись на те, що 3 кожним роком кількість учасників забігів росте (в 2017 році на Київському півмарафоні було більше 8000 учасників), у порівнянні з європейським досвідом - наша аудиторія дуже мала. Наприклад, в 2017 році в Паризькому марафону (дистанція 42,195 км) прийняли участь більше 40000 учасників.

На основі аналізу, узагальнення, порівняння науково-методичної літератури та отриманих емпіричних даних нами було досліджено цільову аудиторію учасників забігів та виявлено особливості залучення різних груп населення до масових оздоровчорекреаційних заходів в Україні. Нами було досліджено соціальні передумови рекреаційної діяльності вітчизняних та зарубіжних оздоровчо-рекреаційних заходів за даними спеціальної літератури. Виявлено, що більшість учасників забігів в Україні - це люди 3 міст мільйонників (Київ, Одеса, Львів), виявлено проблему відсутності бігової культури в багатьох містах та селах України. В рамках ситуації, що склалася в Україні, нами було запропоновано способи залучення більшої кількості людей до занять оздоровчорекреаційними заходами: проведення рекламної кампанії, побудованої на меседжі бігунів, котрі від першої особи розповідали, чому вони біжать і давали зрозуміти, що це може зробити кожна людина; створення онлайн і офлайн програми підготовки для різної аудиторії, від новачків до досвідчених бігунів; проведення лекцій на бігову тематику; створення єдиної бази бігових клубів України з метою покращити підготовку бігунів та розширити аудиторію любителів бігу загалом; створення дистанції в рамках забігу з благодійною метою. На основі отриманих даних розроблено рекомендації із залучення людей до занять оздоровчо-рекреаційною активністю, на прикладі забігів.

Перспективи подальших досліджень полягатимуть в оцінці ефективності розроблених рекомендацій щодо підвищення рівня залучення осіб зрілого віку до оздоровчо-рекреаційної рухової активності.

1. Андрєєва ОВ. Розробка та впровадження технології проектування активної рекреаційної діяльності різних груп населення. Спортивний вісник Придніпров’я, 2015; №1: 4-9.

2. Андрєєва ОВ. Теоретико-методологічні засади рекреаційної діяльності різних груп населення : дис. ... д-ра наук з фіз. виховання і спорту : 24.00.02; НУФВСУ. К., 2014. 400 с.

3. Андрєєва О. Соціально-психологічні чинники, що детермінують рекреаційно-оздоровчу активність осіб різного віку. Теорія і методика фізичного виховання і спорту. 2014; № 3(106): 25-31. 
4. Благій ОЛ, Андрєєва ОВ. Рухова активність як фактор формування здорового способу життя учнівської молоді. Актуальні проблеми фізичного виховання, реабілітації, спорту та туризму : матеріали III-ї міжнар. наук. практ. конф. КПУ. Запоріжжя, 2011: 27-8.

5. Дутчак МВ, Мартин ПМ, Ляшенко ОО, Касьян МЛ, Володін ГА. Моніторинг рівня залучення населення до спорту для всіх: результати всеукраїнського опитування та експертного оцінювання. К.: ПП “Алекс Принтер”, 2008. 18 с.

6. Дутчак МВ. Парадигма оздоровчої рухової активності: теоретичне обгрунтування і практичне застосування. Теорія і методика фізичного виховання і спорту. 2015; № 2: 44-52.

7. Круцевич Т, Андрєєва О. Теоретичні основи дослідження фізичної рекреації як наукова проблема. Спортивний вісник Придніпров’я. 2013; № 1: 5-13

8. Офіційний сайт забігів Run Ukraine. URL: http://runukraine.org.

9. Пасічняк Л, Дутчак М. Теоретичне обгрунтування технології проектування та реалізації програм спортивної анімації в місцях масового відпочинку населення (на матеріалі міських парків). Молодіжний науковий вісник Східноєвропейського національного університету імені Лесі Українки. Фізичне виховання і спорт. 2016; Вип. 21: 68-76.

10. Рингач НО. Громадське здоров’я як чинник національної безпеки : монографія. К. : НАДУ, 2009. 296 с.

11. Стратегии и рекомендации по здоровому образу жизни и двигательной активности: сб.материалов ВОЗ / сост. Е.В. Имас, М.В. Дутчак, С.В. Трачук. К.: НУФВСУ, изд-во “Олимп.лит.”, 2013. 528 с.

12. Цілі сталого розвитку 2016-2030. URL: http://www.un.org.ua/ua/tsili-rozvytku-tysiacholittia/tsili-stalohorozvytku.

13. Andrieieva O, Hakman A, Balatska L. Factors which determine the involvement of elderly people to health and recreational physical activity. Trends and perspectives in physical culture and sports. Suchava, 2016: 41-47.

\section{References}

1. Andrieieva OV. Rozrobka ta vprovadzhennia tekhnolohii proektuvannia aktyvnoi rekreatsiynoi diial'nosti riznykh hrup naselennia. Sportyvnyy visnyk Prydniprov’ia. 2015; №1: 4-9.

2. Andrieieva OV. Teoretyko-metodolohichni zasady rekreatsiynoi diial'nosti riznykh hrup naselennia : dys. ... d-ra nauk z fiz. vykhovannia i sportu : 24.00.02; NUFVSU. K., 2014. 400 p.

3. Andrieieva O. Sotsial'no-psykholohichni chynnyky, shcho determinuiut' rekreatsiyno-ozdorovchu aktyvnist' osib riznoho viku. Teoriia i metodyka fizychnoho vykhovannia i sportu. 2014; № 3(106): 25-31.

4. Blahiy OL, Andrieieva OV. Rukhova aktyvnist' iak faktor formuvannia zdorovoho sposobu zhyttia uchnivs'koi molodi. Aktual'ni problemy fizychnoho vykhovannia, reabilitatsii, sportu ta turyzmu : materialy III-i mizhnar. nauk. prakt. konf. KPU. Zaporizhzhia : 2011: 27-8.

5. Dutchak MV, Martyn PM, Liashenko OO, Kas'ian ML, Volodin HA. Monitorynh rivnia zaluchennia naselennia do sportu dlia vsikh: rezul'taty vseukrains'koho opytuvannia ta ekspertnoho otsiniuvannia. K.: PP "Aleks Prynter", 2008. 18 p.

6. Dutchak MV. Paradyhma ozdorovchoi rukhovoi aktyvnosti: teoretychne obgruntuvannia i praktychne zastosuvannia. Teoriia i metodyka fizychnoho vykhovannia i sportu. 2015; No 2: 44-52.

7. Krutsevych T, Andrieieva O. Teoretychni osnovy doslidzhennia fizychnoi rekreatsii iak naukova problema. Sportyvnyy visnyk Prydniprov'ia. 2013; No 1: 5-13.

8. Ofitsiynyy sayt zabihiv Run Ukraine. URL: http://runukraine.org.

9. Pasichniak L, Dutchak M. Teoretychne obgruntuvannia tekhnolohii proektuvannia ta realizatsii prohram sportyvnoi animatsii $\mathrm{v}$ mistsiakh masovoho vidpochynku naselennia (na materiali mis'kykh parkiv). Molodizhnyy naukovyy visnyk Skhidnoievropeys'koho natsional'noho universytetu imeni Lesi Ukrainky. Fizychne vykhovannia i sport. 2016; No 21: 68-76.

10. Rynhach NO. Hromads'ke zdorov'ia iak chynnyk natsional'noi bezpeky : monograph. K. : NADU, 2009. $296 \mathrm{p}$.

11. Strategii i rekomendatsii po zdorovomu obrazu zhizni i dvigatel'noy aktivnosti: sb.materialov VOZ / sost. E.V. Imas, M.V. Dutchak, S.V. Trachuk. K.: NUFVSU, izd-vo “Olimp.lit.”, 2013. 528 p.

12. Tsili staloho rozvytku 2016-2030. URL: http://www.un.org.ua/ua/tsili-rozvytku-tysiacholittia/tsili-stalohorozvytku.

13. Andrieieva O, Hakman A, Balatska L. Factors which determine the involvement of elderly people to health and recreational physical activity. Trends and perspectives in physical culture and sports. Suchava, 2016: 4147.

\section{Цитування на цю статтю:}

Імас IЄ, Дутчак МВ, Андрєєва ОВ, Кенсицька ІЛ. Підвищення рівня залученості осіб зрілого віку до участі у оздоровчо-рекреаційних заходах. Вісник Прикарпатського університету. Серія: Фізична культура. 2019 Берез 26; 33: 3-10 


\begin{tabular}{|c|c|}
\hline Відомості про автора: & Information about the author: \\
\hline $\begin{array}{l}\text { Iмас Свгеній Вікторович - доктор економічних } \\
\text { наук, професор, ректор Національного університе- } \\
\text { ту фізичного виховання і спорту України (Київ, } \\
\text { Україна) }\end{array}$ & $\begin{array}{l}\text { Imas Yevhenii Viktorovych - Doctor of Economics, } \\
\text { Professor, Rector of the National University of Ukrai- } \\
\text { ne on Physical Education and Sport (Kyiv, Ukraina) }\end{array}$ \\
\hline \multicolumn{2}{|l|}{ https://orcid.org/0000-0003-0641-678 } \\
\hline $\begin{array}{l}\text { Дутчак Мирослав Васильович - доктор наук з фі- } \\
\text { зичного виховання та спорту, професор, проректор } \\
\text { Національного університету фізичного виховання і } \\
\text { спорту України (Київ, Україна) }\end{array}$ & $\begin{array}{l}\text { Dutchak Myroslav Vasylovych - Doctor of Econo- } \\
\text { mics, Professor, Vice-Rector of the National Univer- } \\
\text { sity of Ukraine on Physical Education and Sport (Kyiv, } \\
\text { Ukraina) }\end{array}$ \\
\hline \multicolumn{2}{|l|}{$\begin{array}{l}\text { e-mail: mvd21@ukr.net } \\
\text { https://orcid.org/0000-0001-6823-272 }\end{array}$} \\
\hline $\begin{array}{l}\text { Андрєєва Олена Валеріївна - доктор наук з фізич- } \\
\text { ного виховання та спорту, професор, Національний } \\
\text { університет фізичного виховання і спорту України } \\
\text { (Київ, Україна) }\end{array}$ & $\begin{array}{l}\text { Andrieieva Olena Valeriivna - Doctor of Science of } \\
\text { Physical Education and Sport, Professor, National } \\
\text { University of Ukraine on Physical Education and Sport } \\
\text { (Kyiv, Ukraina) }\end{array}$ \\
\hline \multicolumn{2}{|l|}{ https://orcid.org/0000-0002-2893-1224 } \\
\hline $\begin{array}{l}\text { Кенсицька Ірина Леонідівна - кандидат наук з ф- } \\
\text { ізичного виховання та спорту, Національний уні- } \\
\text { верситет фізичного виховання і спорту України } \\
\text { (Київ, Україна) }\end{array}$ & $\begin{array}{l}\text { Kensytska Iryna Leonidivna - Candidate of Science } \\
\text { (Physical Education and Sport), Associate Professor } \\
\text { (Ph. D.), National University of Ukraine on Physical } \\
\text { Education and Sport (Kyiv, Ukraina) }\end{array}$ \\
\hline
\end{tabular}

\author{
УДК 796.035-053.9:9:616-005.4 \\ doi: 10.15330/fcult.33.10-19
}

Information about the author:

Imas Yevhenii Viktorovych - Doctor of Economics, Professor, Rector of the National University of Ukraine on Physical Education and Sport (Kyiv, Ukraina)

\section{ОЦІККА ЕФЕКТИВНОСТІ КОМПЛЕКСНОЇ ПРОГРАМИ ФІЗИЧНОЇ ТЕРАПІЇ ХВОРИХ ЗІ СТАБІЛЬНОЮ СТЕНОКАРДІЕЮ І-ІІ ФУНКЦІОНАЛЬНОГО КЛАСУ НА ПОЛІКЛІНІЧНОМУ ЕТАПІ}

Вивчено та проаналізовано спеціальну літературу з проблеми застосування засобів фізичної терапї в осіб при стабільній стенокардї напруження (ССН) I-II ФК. Розроблено програму фізичної терапї для хворих із ССН I-II ФК на поліклінічному етапі, яка включає лікувальну гімнастику, лікувальний масаж, фізіотерапію і дієтотерапію. Особливістю иієї програми, яка відрізняла ї̈ від традиційної програми, було включення звукової гімнастики, розширення засобів фізіотерапії завдяки впровадженню надвенного лазерного опромінення крові та ультратону вздовж хребта $i$ дотримання раціонального харчування.

Всього обстежено 33 хворих із ішемічною хворобою серия (ССН I-II ФК). Всі обстежені були чоловіками. Основну групу (ОГ) склали 16 пацієнтів із діагнозом “Іиемічна хвороба серия (ССН I-II ФК). Середній вік обстежуваних иієї групи склав $(53,6 \pm 3,5)$ роки. У групу порівняння (ГП) були відібрані 16

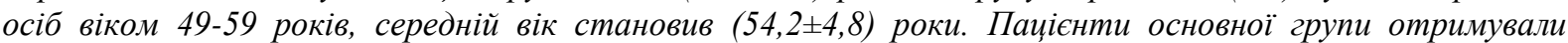
комплекс засобів фізичної терапї̈, які були розроблені в реабілітаційному відділенні поліклініки, за методикою, запропоновану В.М. Мухіним.

За результатами аналізу показників функціонування серцево-судинної системи після закінчення програм фізичної терапії встановлено вірогідне зменшення показника ЧСС в групі порівняння до $(78,4 \pm 1,6)$ уд/хв $(t=3,32 ; p<0,01)$, водночас як в основній групі аналогічні показники мали лише тенденцію до зниження $(t=1,88 ; p>0,01)$. При цььому зниження показників САТ $i$ ДАТ було більш виразним в групі пацієнтів, які отримували розроблену нами програму фізичної терапії $i$ становили, відповідно $(145,4 \pm 2,2)$ i $(84,0 \pm 2,1)$ мм рт. ст. Під впливом заходів проведеної авторської програми у пацієнтів суттєво зменшилась важкість проявів вегетативних і психосоматичних розладів, відбулось покращання загального стану, що підтверджується вірогідним ( $t=2,32$ при $p<0,05)$ зниженням величини показника вегетативного статусу за індексом Кердо до рівня $(1,03 \pm 0,02)$ балу.

Після поліклінічного етапу фізичної терапї толерантність хворих до навантажень збільшилась 8 кілька разів, число нападів стенокардї̈ зменшилося в середньому з 9 до 2-3 на добу. Запропонована ме- 